Scientific Journal Warsaw University of Life Sciences - SGGW

Problems of World Agriculture volume 19 (XXXIV), number 3, 2019: 108-115

DOI: $10.22630 /$ PRS.2019.19.3.51

Vadym A. Tkachuk $^{1}$, Oksana Vitriak ${ }^{2}$

National University of Life and Environmental Sciences of Ukraine

\title{
Perspectives of Development and Enhancement of the Efficiency of the Functioning of Small Forms of Business on the Village
}

\begin{abstract}
The article substantiates the prospects for the development and increase of the functioning efficiency of small farming forms in the countryside. Particular attention is paid to the study of factors that have a negative impact on the farms and households functioning.

Based on the analysis of statistical indicators, it has been established that the most significant factors that have a negative impact on the functioning of small farming forms in the countryside are the difficulty of manufactured products realization, insufficiently effective state support, lack of developed infrastructure, low education level of households' heads. In order to minimize the negative impact of the identified range of problems, it is proposed to introduce preventive measures in the following areas: the state support system improvement, infrastructure development, the production base and resource support improvement, integration relations development.
\end{abstract}

Keywords: agriculture, small farming forms, agricultural production.

JEL Classification: R11

\section{Problem statement}

The development of the multi-apartment economy is that the socio-economic situation is the main means of managing, which it is an integral part of agricultural production. Small forms of economic accounting are one of the most widespread and basic forms economic activity of the population, which it's not only characterize the relations between economic agents for the agricultural products production with the corresponding satisfaction of the population needs in food products, but also to a large extent contribute to the food security provision of the state.

Small economic accounting forms contribute to solving social countryside problems, sustainable development of rural areas, ensuring population employment, preserving rural lifestyle, folk traditions, cultural heritage. Their role in the labor output of young people, the preservation and productive and social experience transfer from older generations to younger. All the above-mentioned makes urgently necessary the justification of the longterm development and effectiveness influence of the small forms functioning of farming in the countryside.

\footnotetext{
${ }^{1}$ Doctor of Economics, Professor at the Department of Labor Economics and Social Development of the National University of Life and Environmental Sciences of Ukraine.; Heroiv Oborony Str.15, Kyiv, Ukraine, 03041; e-mail: vadtkachuk@hotmail.com; https://orcid.org/0000-0002-9684-8625.

${ }^{2} \mathrm{PhD}$ student in Economics; Heroiv Oborony Str.15, Kyiv, Ukraine, 03041; e-mail: vitriak@nubip.edu.ua; https://orcid.org/0000-0002-3884-9646
} 


\section{Recent sources, researches and publications analysis}

Development problems of the agrarian economy in the context of many aspects were dealt by such well-known scholars as A. Yu. Amosov (2008), V. K. Zbarsky (2016), N. I. Demchuk (2018). Their works are devoted to theoretical and methodological principles of farming development with an emphasis on its social and industrial orientation. Particular attention deserve works focused on the consequences study of reforming the agrarian sector, the effective mechanisms introduction of state support to agriculture, promising directions for the rural areas development, among which it should be noted scientific advances T.G. Marenich (2015), V.P. Riabokon (2015), M.I. Malik (2018), V.V. Yurchyshina [7] et al.

Taking into account the contribution of well-known scholars, whose work formed the basis for the theoretical and methodological research of the development problem in agricultural sector in Ukraine, in-depth study, in our opinion, needs a question regarding the prospects of management small forms development, such as this form are significant part of agricultural production.

The research goal. The goal of the article is substantiating the prospects for the development and increase of the efficiency of small form functioning of farming in the countryside.

\section{Research results}

All forms of management in the agrarian sphere have its own peculiarities, determined both by the specifics of agriculture and the internal nature agricultural forms of activity. The forms of management in the agro-industrial complex of Ukraine are represented by farms and households. The mentioned forms of economic activity differ relatively low level of economic production efficiency, low adaptive capacity, low level of material and technical base development, weak level of technological development, limited access to industrial objects, market and logistic infrastructure, insufficient level of involvement in consumer-to-consumer relations and agro-industrial integration. At the same time, according to the State Statistics Service of Ukraine, the contribution of small forms of farming in rural areas to agricultural production is $43 \%$, which is provided by almost 15.0 million households (Statistical bulletin ... 2017). In 2018, according to preliminary estimates, small Ukrainian business forms produced agricultural produce 130.36 million, which agricultural enterprises account for $16.7 \%$ agricultural production, and $83.3 \%$ households. They did not only provide significant employment of the rural population, but also played a significant role in both food supply of the country and in the cash incomes formation of rural households. The analysis of the agricultural products dynamics by farms category (Table 1) showed a gradual tendency to increase the share of production from of farms, indicating the development of this category. Increasing the efficiency of competition between farms and agricultural enterprises is observing in the grain and vegetables production. Farmers have achieved some success in milk production, but the level of technology that they use does not allow them are competing effectively in the production of meat and eggs, although the presence of large areas of natural forage land creates prerequisites for the development of competitive meat cattle breeding. In the event of an increase in demand for environmentally friendly products, the producers can take this market niche using their adaptive potential. The decline in the agricultural production share and the increase in the agricultural enterprises share in comparison with 2005 shows a 


\section{V.A. Tkachuk, O. Vitriak}

tendency towards business consolidation, but still, the agricultural production share from farms remains rather large.

Table 1 . Analysis of the agricultural products dynamics by farms category

\begin{tabular}{l|rrrrrrrr}
\multicolumn{1}{c|}{$\begin{array}{c}\text { Farms } \\
\text { category }\end{array}$} & \multicolumn{2}{|c}{$\mathbf{2 0 0 5}$} & \multicolumn{2}{c}{$\mathbf{2 0 1 0}$} & \multicolumn{2}{c}{$\mathbf{2 0 1 5}$} & \multicolumn{2}{c}{$\mathbf{2 0 1 8}$} \\
& $\begin{array}{c}\text { million } \\
\text { UAH }\end{array}$ & $\begin{array}{c}\text { share } \\
\text { in total }\end{array}$ & $\begin{array}{c}\text { million } \\
\text { UAH }\end{array}$ & $\begin{array}{c}\text { share in } \\
\text { total }\end{array}$ & $\begin{array}{c}\text { million } \\
\text { UAH }\end{array}$ & $\begin{array}{c}\text { share in } \\
\text { total }\end{array}$ & $\begin{array}{c}\text { million } \\
\text { UAH }\end{array}$ & $\begin{array}{c}\text { share in } \\
\text { total }\end{array}$ \\
\hline $\begin{array}{l}\text { Facilities of all } \\
\text { categories }\end{array}$ & 179605,8 & 100 & 194886,5 & 100 & 239467,3 & 100 & 249157 & 100 \\
$\begin{array}{l}\text { Agricultural } \\
\text { enterprises }\end{array}$ & 72764,7 & 35,96 & 94089 & 42,14 & 131918,6 & 47,19 & 140535,2 & 47,67 \\
Farms & 8177,5 & 4,55 & 11965,8 & 6,14 & 18909,3 & 7,90 & 21743,1 & 8,73 \\
Households & 106841,1 & 59,49 & 100797,5 & 51,72 & 107548,7 & 44,91 & 108621,8 & 43,60 \\
\hline
\end{tabular}

Source: own Authors' calculation based on Statistical bulletin ... 2017.

In addition, the comparison of statistical indicators concerning the number of products received in rural households and the sale products indicators of own production by rural households (Fig. 1), shows the surplus of production in almost all major agricultural products categories.

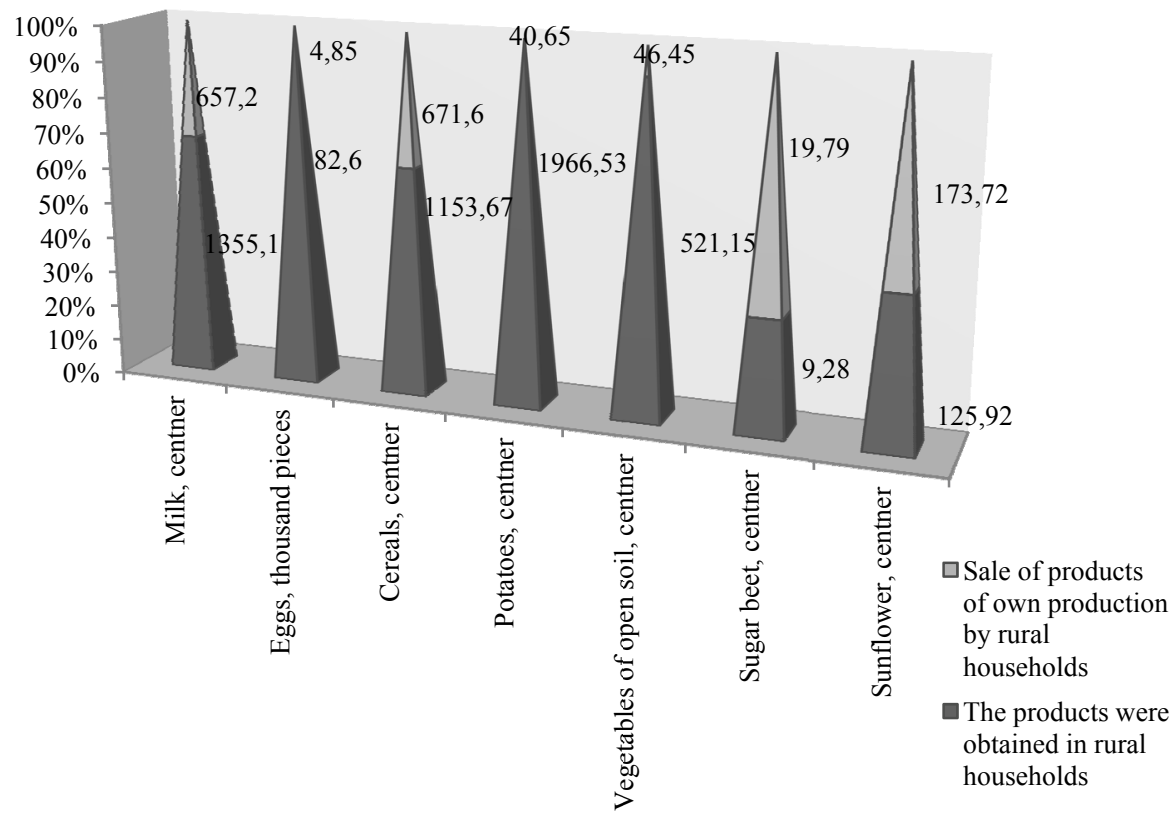

Fig. 1. Representation of production indicators and agricultural products sale of households by main crop and livestock production types

Source: Statistical collection... 2017. 
The production of farm households is mainly considered only as a source of rural families self-sufficiency by food products. In fact, this category of farms has a significant surplus of agricultural production, which, under favorable conditions for the market infrastructure development (proximity markets, accessibility of transport, etc.) can be realized on local markets.

Despite the large volumes of small forms farming production in the countryside, their involvement in the field of commodity exchange of agricultural products and food market system remains low.

Typology of small management forms is carrying out on the following grounds: on the merchantability level (consumer goods, commodity-enterprise, commodity-consumer, highquality farms); by specialization (non-specialized farms, farms of broad specialization, farms specialization, cattle-breeding farms, mixed farms); by the education level of the head of the economy (without education, with secondary education, with vocational education, with higher education); by the registration degree (farms registered as individual entrepreneurs, farms without registration). As one of the factors limiting the importance of small management forms in the agricultural sector, the level of education of farms heads should be noted (Fig. 2).

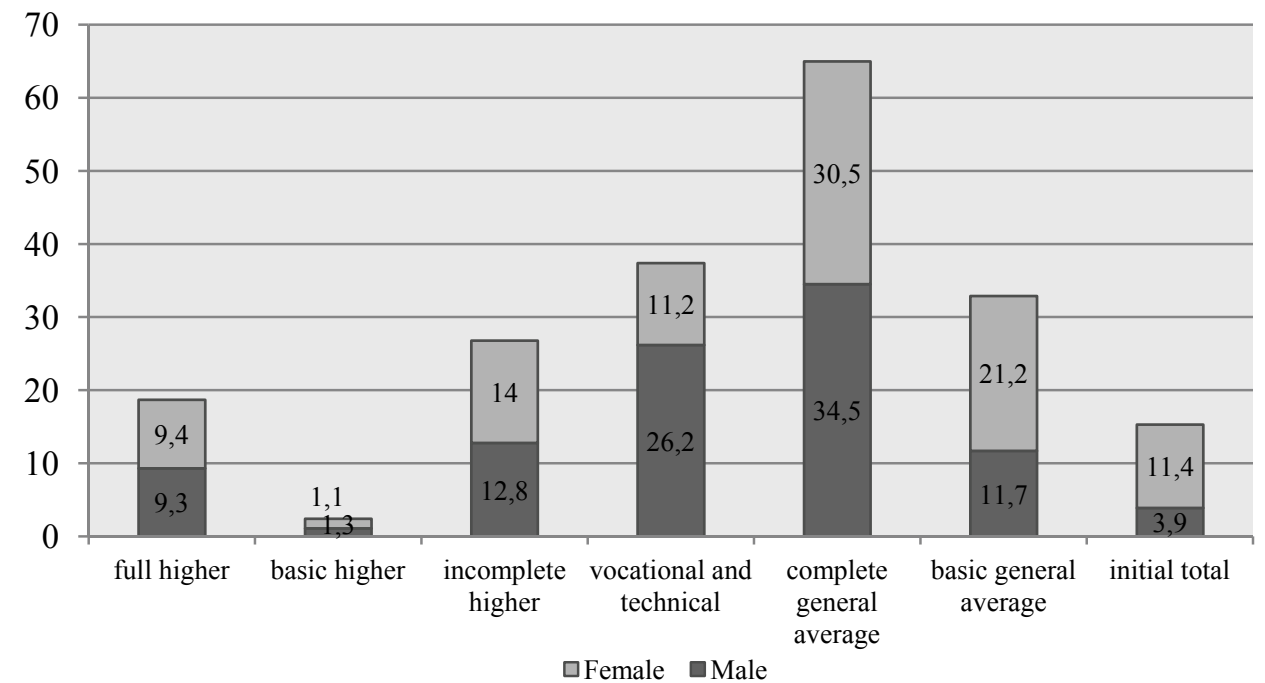

Fig. 2. Distribution of managers of small management forms in rural areas by gender and education, $\%$

Source: Statistical collection... 2017.

The statistics show a low level of education in the heads of small management forms, with only $9.3 \%$ men and $9.4 \%$ women having complete higher education, which, consequently, has an impact on the quality of the farms management they head.

Government actions aimed at solving this problem are implemented through the CMU "On approval of a plan of measures for the implementation of the rural development Concept", which sets out a number of measures for the period 2017-2025 in the direction "Education and Information and Consultative Security" (Resolution... 2017).

A critical analysis of the leading scholars' views (Demchuk 2018; Ryabokon 2015; Malik, Shpiculyak 2018) and statistical reporting indicators has shown that small forms of 
rural economy experience certain legal, organizational, economic, and social problems, the most important are:

$\checkmark$ problem of produced agricultural products realization;

$\checkmark$ due to the lack of agricultural lending cooperation development in rural areas, poor access to financial and credit resources;

$\checkmark$ insufficiently effective state support;

$\checkmark$ insufficient supply of high-yielding seeds, productive livestock, fertilizers, pesticides and other material resources;

$\checkmark$ absence of a well-established effective system of agronomy, veterinary, zootechnical, as well as production service;

$\checkmark$ lack of agricultural machinery and equipment;

$\checkmark$ low level of education of heads of small management forms.

The most significant factor that has a negative impact on the functioning of small farming forms in the countryside is the realizing manufactured products difficulty. In this case, the main limiter is not the lack of demand for agricultural products and food and the lack of sales infrastructure (Marenich 2015). Therefore, small producers are forced to sell their products to intermediaries at their cost. This problem is related to the lack of both marketing structures operating in the interests of producers and the infrastructure of agricultural products primary processing, storage and transportation infrastructure.

Another, not less negative factor hindering the development of small management forms in the agro-industrial complex, is the difficult availability of financial resources, due to the large size of the required mortgage base in obtaining loans.

It should be noted that the fact that small management forms in the agro-industrial complex are more economically unstable, compared with large agricultural enterprises. They are influenced by both internal and external factors. Internal and external factors that shape the strengths of small farms:

$\checkmark$ advantageous territorial location of the region;

$\checkmark$ close affiliation to the markets;

$\checkmark \quad$ well-developed transport network;

$\checkmark$ introduction of a ban on the agricultural products importation from individual countries;

$\checkmark \quad$ state support, in the form of grants, subsidies.

Internal and external factors that shape the weaknesses of small management forms:

$\checkmark$ natural climate conditions;

$\checkmark$ insufficient credit;

$\checkmark$ insufficiently developed sales policy of agricultural products;

$\checkmark$ high cost of energy resources;

$\checkmark \quad$ low level of material and technical equipment (Malik, Shpiculyak 2018).

To solve all the above problems should focus on the directions of development and improvement of the functioning efficiency of small farming forms in the countryside, which are presented in Fig. 3. 


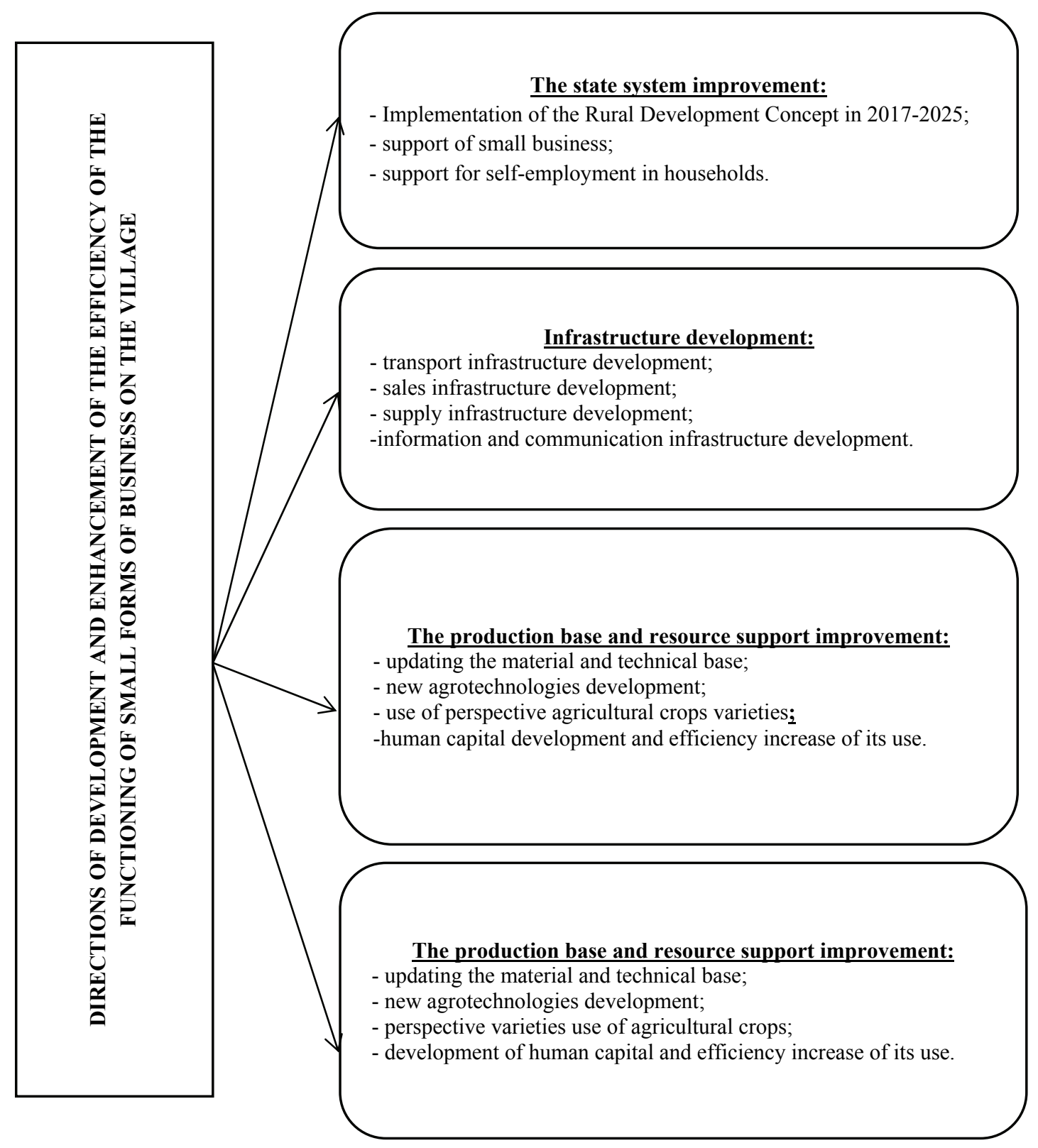

Fig. 3. Development and increase directions of functioning efficiency of small farming forms in the countryside Source: Marenich 2015.

The first direction is related to the need to simplify the procedure for state registration, to facilitate access to financial resources (budget, extrabudgetary), to establish a system of 


\section{V.A. Tkachuk, O. Vitriak}

guarantees for lending, support for the small business sector, support rural development, support local producers as an economic basis for the human capital reproduction and support for development agriculture branches as the basis of food security in the country.

The second area includes activities related to the infrastructural support development for the farms and households' activities. Among the top-priority measures in this area are: industrial infrastructure system development, supply infrastructure, procurement, storage and agricultural products transportation, as well as information and communication infrastructure.

Production base improvement and resource provision is based on the material and technical base modernization, the human potential development, new technologies for growing crops and keeping livestock and poultry development, creating the preconditions for increasing their productivity and productivity, as well as ensuring the continuity of the reproduction process.

Integration processes implementation involves the selection of optimal interaction forms between economic actors in the agrarian sector in the production relations development and consumer cooperation, agro-industrial integration.

\section{Conclusions and suggestions}

Thus, in order to ensure sustainable development and effective activity of small management forms in rural areas, it is necessary to expand the specialization of agricultural production, to fully apply the latest technological developments in the production and agricultural products processing. Solving problems in many ways will be facilitated by program-targeted approaches in the field. Infrastructure development and state support for small forms of farming in the countryside.

As one of the perspective directions of the integration relations development can be considered the possibility of forming product or territorial integrated cluster type structures that positively affect the ability to integrate into the market environment and successfully compete with representatives of both small and medium and large businesses.

\section{References}

Amosov, O.Yu. (2008). Farmers as a form of entrepreneurship in the agrarian sector. AgroSvit. 8, 46-51.

Demchuk, N.I. (2018). Production potential of Ukrainian farms: current state and development prospects. Modern trends in the development of regions and sectors of the national economy: a monograph. Dnieper: Thresholds, 109-126.

Formuvannia ob'iednanykh terytorialnykh hromad: stan, problemni pytannia ta shliakhy yikh vyrishennia (Formation of united territorial communities: state, problem issues and ways of their solution). Natsionalnyi Instytut Stratehichnykh Doslidzhen. Retrived from: http://www.niss.gov.ua/content/articles/files/terutor_gromad-86ead.pdf.

Malik, M.Y., Shpiculyak, O.G. (2018). Trends and prospects of development of personal peasant farms. Economy APK 1, 11-19. 
Marenich, T.G. (2015). Farmers in Ukraine and prospects for its functioning. The Bulletin of the Kharkov National Technical University of Agriculture named after Petr Vasilenko 161, 37-50.

Resolution of the Cabinet of Ministers of Ukraine dated 19 July 2017 No. 489-r "On Approval of the Plan of Measures to Implement the Concept of Rural Development". Retrived from: https://zakon.rada.gov.ua/laws/ show/en/489-2017-\%D1\%80\#n8

Ryabokon, V.P. (2015). Problems of formation of socio-economic conditions of Ukrainian village development. Economy of Agroindustrial Complex, 9, 68-74.

Serohin, S.M., Sharov, Yu.P., Borodin, Ye.I., Honcharuk, N.T. (2016). Upravlinnia stratehichnym rozvytkom ob'iednanykh terytorialnykh hromad: innovatsiini pidkhody ta instrumenty: monohrafiia (Management of Strategic Development of the United Territorial Communities: Innovative Approaches and Tools: Monograph). Dnipropetrovsk: DRIDU NADU.

Statistical bulletin "The main agricultural characteristics of rural households in 2017" (2017). Derzhkomstat of Ukraine, $82 \mathrm{p}$.

Statistical collection "Agriculture of Ukraine" (2017). Derzhkomstat of Ukraine, 82 p.

Yurchyshyn, V.V. (2013). Modern agrarian transformations in Ukraine: monograph. Academy of Sciences of Ukraine, DU "Institute of Economics. and predicting. NASU", $424 \mathrm{p}$.

Zbarskii, V.K., Kalchenko, S.V., Eremenko, D.V. (2016). Optimization of the method of estimation of competitiveness of high-quality farms of family-labor type. Scientific Herald of Uzhgorod University. Economy 1(2), 272-278.

For citation:

Tkachuk V.A., Vitriak O. (2019). Perspectives of Development and Enhancement of the Efficiency of the Functioning of Small Forms of Business on the Village. Problems of World Agriculture, 19(3), 108-115; DOI: 10.22630/PRS.2019.19.3.51 